worry, could taint the entire openaccess movement. "I think Beall has taken a brave and principled stand in publishing this, at no small risk to himself," says Douglas Sipp, an expert in science policy and ethics at the RIKEN Center for Developmental Biology in Kobe, Japan, who studies the open-access movement in Asia.

Beall says that he has been the target of vicious online comments, and last December he was the subject of an online campaign to create the false impression that he was extorting fees from publishers to re-evaluate their status on his list. The Canadian Center of Science and Education, a company based in Toronto that publishes many open-access journals and is on Beall's list, is now threatening to sue him for alleged defamation and libel. But even some experts in scholarly publishing are uncomfortable with Beall's blacklist, arguing that it runs the risk of lumping publishers that are questionable together with those that could be bona fide start-ups simply lacking experience in the publishing industry. Matthew Cockerill, managing director of BioMed Central, an open-access publisher based in London, says that Beall's list "identifies publishers which Beall has concerns about. These concerns may or may not be justified."

\section{RISING TIDE}

As a research librarian, Beall has been in prime position to watch the dramatic changes that have taken place in scientific publishing since the rise of the open-access movement about a decade ago. In the conventional subscription-based model, journals bring in revenue largely through selling print or web subscriptions and keeping most online content locked behind a paywall. But in the most popular model of open access, publishers charge an upfront 'author fee' to cover costs - and to turn a profit, in the case of commercial publishers - then make the papers freely available online, immediately on publication.

The open-access movement has spawned many successful, wellrespected operations. PLOS ONE, for example, which charges a fee of US $\$ 1,350$ for authors in middle- and high-income countries, has seen the number of articles it publishes leap from 138 in 2006 to 23,464 last year, making it the world's largest scientific journal. The movement has also garnered growing political support. In the past year, the UK and US governments, as well as the European Commission, have thrown their weight behind some form of open-access publishing. And scarcely a week goes by without the appearance of new author-pays, open-access publishers, launching single journals or large fleets of them.

Many new open-access publishers are trustworthy. But not all. Anyone with a spare afternoon and a little computing savvy can launch an impressive-looking journal website and e-mail invitations to scientists to join editorial boards or submit papers for a fee. The challenge for researchers, and for Beall, is to work out when those websites or e-mail blasts signal a credible publisher and when they come from operations that can range from the outright criminal to the merely amateurish.

In one e-mail that Beall received and shared with Nature, a dental researcher wrote that she had submitted a paper to an open-access journal after she "was won over by the logos of affiliated databases on the home page and seemingly prestigious editorial board". But the researcher, who prefers to remain anonymous, says that she became concerned about the peerreview process when the article was accepted within days and she was not sent any reviewers' comments. She says that last week several months after her original submission - she was sent page proofs that match the submitted manuscript, and that she still has not seen reviewers' comments.

Complaints like this prompted Beall to coin the term predatory publisher and to compile his first list of them, which he published in 2010. He now estimates that his zeal for investigating publishers takes up 20-25 hours a week, squeezed in around his day job. Beall says that he is motivated partly by his sense of duty, as an academic librarian, to evaluate online resources and to help patrons to "recognize scholarly publishing scams and avoid them", and partly by the "private and very positive feedback" he receives from researchers and librarians.

But Beall's critics assert that he often relies heavily on analysis of publishers' websites rather than detailed discussions with publishers, and that this might lead to incorrect or premature conclusions. "One of the major weaknesses of Jeffrey Beall's methodology is that he does not typically engage in direct communication with the journals that he has classified as predatory," says Paul Peters, chief strategy officer at Hindawi Publishing Corporation, based in Cairo, and president of the Open Access Scholarly Publishers Association (OASPA), based in The Hague, the Netherlands. A set of Hindawi's journals appeared on a version of Beall's list because he had concerns about their editorial process, but has since been removed. "I reanalysed it and determined that it did not belong on the list," he says. "It was always a borderline case."

Another concern, say Beall's critics, is that he risks throwing undue suspicion on start-up publishers. "Although rapid launches of many journals may well correlate negatively with journal quality, it is certainly not enough in and of itself to warrant describing a publisher as predatory," says Cockerill, who is also a board member of the OASPA. "Similarly, some publishers identified on Beall's list are guilty of poor copy-editing and user-interface design on their websites," he says. "Again, this is, at best, circumstantial evidence for problems with the scholarly standard of the material they publish."

OMICS Group, based in Hyderabad, India, is on Beall's list. One researcher complained in an e-mail to Beall that she had submitted a paper to an OMICS journal after receiving an e-mail solicitation but learned that she had to pay a fee to publish it only from a message sent by the journal after the paper had been accepted. "To my horror, 
I opened the file to find an invoice for $\$ 2,700$ !" she wrote. "This fee was not mentioned anywhere obvious at the time I submitted my manuscript." (Nature was unable to contact this researcher.) Beall says that OMICS journals do not show their author fees prominently enough on their journal websites or in e-mails that they send to authors to solicit manuscript submissions.

Srinubabu Gedela, director of OMICS Group, says that articlehandling fees are displayed clearly on the 'Instructions for Authors' web page for each OMICS journal. Gedela adds that he would assume researchers would be aware that such open-access journals charge author fees. He says that OMICS Group is "not predatory" and that its staff and editors are acting in "good faith and confidence" to promote openaccess publishing.

Publishers in developing countries and emerging economies are at particular risk of being unfairly tarred by Beall's brush, critics say.

Many open-access publishers are springing up in India and China, for example, where swelling researcher ranks are creating large publishing markets. Pressure to publish is often intense in developing countries, and vanity presses could attract unscrupulous researchers keen to pad out their CVs. But respectable domestic publishers could have an important role by helping to address local science issues, such as those related to crops, diseases or environmental problems.

"It is important that criteria for evaluating publishers and journals do not discriminate [against] publishers and journals from other parts of the world," says Lars Bjørnshauge, managing director of the Directory of Open Access Journals (DOAJ), based in Copenhagen, which lists open-access journals that have been reviewed for quality. New publishing outfits may legitimately use aggressive marketing tactics to recruit authors, and they may have yet to polish their websites, editorial boards and peer-review procedures.

"Some are embarrassingly, toe-cringingly amateurish, but predatory is a term that, I think, implies intent to deceive," says Jan Velterop, a former science publisher at Nature Publishing Group and elsewhere who is now working with several start-ups to promote innovative ways to publish science data. Damage could be done if "a damning verdict is given to otherwise honest, though perhaps amateurish, attempts to enter the publishing market", he says.

\section{QUESTIONING THE VERDICT}

For researchers involved in journals whose publishers have appeared on Beall's blacklist, the verdict can be unsettling. David Warhurst, a malaria researcher at the London School of Hygiene and Tropical Medicine, is the unpaid editor-in-chief of Malaria Chemotherapy, Control \& Elimination, an open-access, peer-reviewed journal owned by Ashdin Publishing, a company that has offices in Cairo and Honnelles, Belgium, and that is on Beall's list.

Warhurst says that he was initially reluctant to take up the invitation he received two years ago to become the journal's editor-in-chief, because he found that the publishers did not have a journal registered with the publication index PubMed. But "certainly I do not believe that this is a toxic journal", he says. The journal is still in its launch phase, and refereeing of
( as fair and honest as I can be when I am making judgements".

Beall says that he usually gives blog posts a 'cooling-off' period between writing and publishing them. Last month, he announced an appeals process in which a three-person advisory board will conduct a blinded review and then recommend whether the publisher or journal should stay on the list. And to improve transparency, Beall last August posted a set of criteria that he says he uses to assess publishers, including an evaluation of their content and practices based on standards established by organizations such as the OASPA. Rick Anderson, a library dean at the University of Utah in Salt Lake City, says that Beall's criteria "make a lot of sense" and also allow for distinctions between truly exploitative publishers and those that are just sloppy.

Bjørnshauge feels that the entire problem needs to be kept in perspective. He estimates that questionable publishing probably accounts for fewer than $1 \%$ of all author-pays, open-access papers - a proportion far lower than Beall's estimate of 5-10\%. Instead of relying on blacklists, Bjørnshauge argues, open-access associations such as the DOAJ and the OASPA should adopt more responsibility for policing publishers. He says that they should lay out a set of criteria that publishers and journals must comply with to win a place on a 'white list' indicating that they are trustworthy. The DOAJ, he says, is now compiling a list of new, more stringent criteria. To help clean up practices, he adds, research funders should pay author fees only to such white-listed publishers. Meanwhile, he urges researchers to be as cautious when shopping online for publishers as when shopping for anything else (see 'Buyer beware'). "Examine the company you are about to deal with," he says.

Beall says that he supports such efforts. "If someone can figure out a better way, that would be great, and I will defer to them," he says. "I wish them success." But he is sceptical about whether a white list would be able to keep up with the surge of new publishers, and believes that his blacklist provides more immediate warning. That, however, depends on whether he can keep up. "I did not expect and was unprepared for the exponential growth of questionable publishers that has occurred in the past two years," he says.

Declan Butler is a senior reporter for Nature based in France. 